\title{
Hubungan Pendidikan dan Daya Saing Bangsa
}

\author{
Muhamad Faizul Amirudin \\ Sekolah Tinggi Agama Islam Bumi Silampari Lubuklinggau \\ amirudin.mfgcf@gmail.com
}

\begin{abstract}
This paper aims to find out how the relationship between education and national competitiveness. Because from the results of a survey conducted by The Global Compliance Report the position of the competitiveness of the Indonesian nation always rises down from year to year. By looking at the various data, is there an educational factor that determines the position of national competitiveness. From the results of several documents and articles both journals and books it turns out that one of the pillars of the nation's competitiveness is education. Education is one of the efforts of a nation in improving the quality of its human resources. So to improve the quality of human beings is also required to make improvements to equitable education and quality of education. Because education is what will make qualified human beings a driver of national development towards a nation that has high competitiveness.
\end{abstract}

Keywords: Relations, Education, Nation Competitiveness

\begin{abstract}
Abstrak: Tulisan ini bertujuan untuk mengetahui bagaimana hubungan antara pendidikan dan daya saing nasional. Karena dari hasil survei yang dilakukan oleh Global Compliance Report, posisi daya saing bangsa Indonesia selalu naik turun dari tahun ke tahun. Dengan melihat berbagai data, adakah faktor pendidikan yang menentukan posisi daya saing nasional. Dari hasil beberapa dokumen dan artikel baik jurnal maupun buku ternyata salah satu pilar daya saing bangsa adalah pendidikan. Pendidikan adalah salah satu upaya suatu bangsa dalam meningkatkan kualitas sumber daya manusianya. Maka untuk meningkatkan kualitas manusia juga dituntut untuk melakukan perbaikan pendidikan yang merata dan kualitas pendidikan. Karena pendidikanlah yang akan menjadikan manusia yang berkualitas menjadi pendorong pembangunan nasional menuju bangsa yang memiliki daya saing tinggi.
\end{abstract}

Kata kunci: Hubungan, Pendidikan, Daya Saing Bangsa

Belajea: Jurnal Pendidikan Islam, Vol. 4, No. 1, 2019; 35-48

p-ISSN 2548-3390; e-ISSN 2548-3404, DOI: 10.29240/belajea.v4i1.723

available online at: http://journal.staincurup.ac.id/index.php/belajea 


\section{Pendahuluan}

Pendidikan dalam sebuah Negara adalah bagian yang sangat urgen. Karena pendidikan merupakan sebuah proses yang sistematis dalam menghasilkan Sumber Daya manusia (SDM) yang dibutuhkan dalam membangun Negara. Sebesar atau sebanyak apapun Sumber Daya Alam (SDA) yang dimiliki sebuah Negara tanpa didukung oleh SDM maka tidak akan mampu untuk menjadikan kemakmuran sebuah Negara. Karena pentingnya pendidikan tersebut bukan hanya dalam pengelolaan SDA tetapi juga dalam hal sosial, budaya, politik, pertahanan keamanan dan lainnya. Dalam rencana strategis departemen pendidikan nasional menyatakan pembangunan pendidikan nasional ke depan didasarkan pada paradigm membangun manusia Indonesia seutuhnya, yang berfungsi sebagai subyek yang memiliki kapasitas untuk mengaktualisasikan potensi dan dimensi kemanusiaan secara optimal. Dimensi kemanusiaan itu mencakup tiga hal paling mendasar, yaitu afektif, yang tercermin pada kualitas keimanan, ketakwaan, akhlak mulia termasuk budi pekerti luhur serta kepribadian unggul, dan kompetensi estetis; kognitif, yang tercermin pada kapasitas pikir dan daya intelektualitas untuk menggali dan mengembangkan serta menguasai ilmu pengetahuan dan teknologi; dan psikomotorik, yang tercermin pada kemampuan mengembangkan keterampilan teknis, kecakapan praktis, dan kompetensi kinestetis. ${ }^{1}$

Dimensi-dimensi di atas akan menentukan kualitas SDM Negara Indonesia dalam persaingan di dunia. Untuk itu perlunya mutu pendidikan di Indonesia agar mampu bersaing dengan bangsa-bangsa lain, apalagi untuk saat ini telah memasuki revolusi industry 4.0 yang menjadi tantangan sekaligus peluang bagi bangsa Indonesia untuk berkompetisi dalam persaingan global. Karena SDM yang bermutu hanya bisa dihasilkan dari pendidikan yang bermutu. Sementara itu yang menjadi permasalahan sementara ini berupa pemerataan pedidikan, mutu pendidikan dan pendanaan yang masih menghambat pendidikan di Indonesia.

Peringkat pendidikan Indonesia di dunia berdasarkan hasil survey capaian nilai Programme for Internasional Student Assessment (PISA) Indonesia untuk 2015 meningkat enam peringkat dari peringkat 71 pada 2012 menjadi 64 dari 72 negara. Walaupun peringkatnya meningkat pada kategori sains, Indonesia masih masuk jajaran negara dengan kualitas sains terendah yang 
menempati posisi ke 9 terendah dengan skor $403 .^{2}$ Selanjutnya pada survey yang dilakukan Human Development indices and indicators (HDI) pada tahun 2017 Indonesia berada pada posisi 116 dari 189 negara dengan salah satu indikatornya partisipasi dalam bidang pendidikan. ${ }^{3} \mathrm{Hal}$ inilah yang kemudian juga berdampak terhadap daya saing Indonesia dengan Negara-negara lain di dunia dalam kompetisi di era global.

Tulisan ini akan membahas tentang hubungan pendidikan dan daya saing bangsa. Dengan metode library research penulis akan membahas mengenai hubungan pendidikan dan daya saing bangsa. Teori yang digunakan untuk membedah permasalahan tersebut diantaranya teori tentang pendidikan, daya saing bangsa, dan pembangunan SDM, dengan menggunakan sumber data buku-buku, jurnal, artikel internet serta dokumen-dokumen lainnya yang terkait. Analisis yang digunakan yaitu descriptive analysis.

\section{Pengertian, fungsi dan Tujuan Pendidikan}

Pendidikan Menurut UU No 20 Tahun 2003 diartikan sebagai usaha sadar dan terencana untuk mewujudkan suasana belajar dan proses pembelajaran agar peserta didik secara aktif mengembangkan potensi dirinya untuk memiliki kekuatan spiritual keagamaan, pengendalian diri, kepribadian, kecerdasan, akhlak mulia, serta keterampilan yang diperlukan dirinya, masyarakat, bangsa dan Negara. Lebih lanjut dinyatakan Pendidikan nasional adalah pendidikan yang berdasarkan Pancasila dan UUD Negara Republik Indonesia Tahun 1945 yang berakar pada nilai-nilai agama, kebudayaan nasional Indonesia dan tanggap terhadap tuntutan perubahan zaman. ${ }^{4}$

Menurut Fuad Ihsan Pengertian pendidikan secara sederhana adalah "Usaha manusia untuk menumbuhkan dan mengembangkan potensi-potensi pembawaan baik jasmani maupun rohani sesuai dengan nilai-nilai yang ada didalam masyarakat dan kebudayaan". ${ }^{5}$ Sedangkan menurut Arifin Pendidikan sebagai usaha membina dan mengembangkan pribadi manusia; aspek rohaniah dan jasmaniah, juga harus berlangsung secara bertahap. maka "suatu

2"Indonesia Masuk 10 Negara Dengan Kualitas Sains Terendah | Databoks," accessedJanuary29,2019,https://databoks.katadata.co.id/datapublish/2016/12/21/indonesiamasuk-10-negara-dengan-kualitas-sains-terendah.

${ }^{3}$ United Nations, "Human Development Indices and Indicators: 2018 Statistical Update,” 2018, http://hdr.undp.org/sites/default/files/hdr2018_technical_notes.pdf.

${ }^{4}$ Republik Indonesia, "Undang-Undang No 20 Tahun 2003 Tentang Sisdiknas," Pub. L. No. 20 (2003).

${ }^{5}$ Fuad Ihsan, Dasar-Dasar Pendidikan (Jakarta: PT.Rineka Cipta, 2005), hlm.1. 
kematangan yang bertitik akhir pada optimalisasi perkembangan atau pertumbuhan, baru dapat tercapai bilamana berlangsung melalui proses demi proses ke arah tujuan akhir perkembangan atau pertumbuhannya".

Dari beberapa pengertian di atas terdapat persamaan beberapa pendapat ahli tersebut yang pada intinya pendidikan merupakan sebuah usaha menumbuhkembangkan potensi-potensi peserta didik baik dari aspek jasmani maupun aspek rohani dengan nilai-nilai agama dan kebudayaan masyarakat. Pendidikan disini diharapkan mampu menjadikan potensi peserta didik dapat tumbuh dan berkembang secara optimal sehingga mampu mencapai cita-cita suatu bangsa yang diinginkan.

\section{Fungsi dan Tujuan Pendidikan}

Fungsi pendidikan nasional tertera dalam UU No 23 Tahun 2003 bab II Pasal 3 yaitu mengembangkan kemampuan dan membentuk watak serta peradaban bangsa yang bermartabat dalam rangka mencerdaskan kehidupan bangsa. ${ }^{7}$ Menurut arifin fungsi pendidikan adalah menyediakan fasilitas yang dapat memungkinkan tugas pendidkan dapat berjalan lancar. ${ }^{8}$ Sedangkan dalam pendidikan Islam Menurut Bukhri Umar fungsi pendidikan adalah realisasi untuk menumbuhkan atau mengaktualisasikan potensi ${ }^{9}$ dan realisasi untuk menyampaikan atau transformasi nilai-nilai budaya islami. ${ }^{10}$ Artinya fungsi pendidikan sebagai realisasi dari apa yang dicita-citakan suatu pendidikan itu sendiri yang tercantum dalam pengertian pendidikan melalui penyediaan fasilitas dalam rangka mencerdaskan kehidupan bangsa. Cerdas yang dimaksud disini bukan hanya pada aspek intelektual tapi juga memilki kecerdasan spiritual dan emosional sehingga selain menguasai dalam bidang Iptek juga memilki keimanan dan ketakwaan, berkahlak mulia, dan berkarakter, yang sesui dengan nilai-nilai budaya bangsa dan agama.

Tujuan pendidikan dapat kita lihat dalam UU no 20 tahun 2003 bahwa tujuan pendidikan nasional yaitu untuk mengembangkan potensi peserta didik agar menjadi manusia yang beriman dan bertakwa kepada Tuhan Yang Maha Esa, berakhlak mulia, sehat, berilmu, cakap, kreatif, mandiri, dan menjadi warga

\footnotetext{
${ }^{6}$ Muzayyin Arifin, Filsafat Pendidikan Islam (Jakarta: PT. Bumi Aksara, 2003), hlm. 12. ${ }^{7}$ Indonesia, Undang-Undang No 20 Tahun 2003 tentang Sisdiknas.

${ }^{8}$ Arifin, hlm. 34

${ }^{9}$ Bukhori Umar, Ilmu Pendidikan Islam, 1st ed. (Jakarta: Amzah, 2010), hlm. 69.

${ }^{10}$ Umar., hlm 79
} 
negara yang demokratis serta bertanggung jawab. ${ }^{11}$ Bila kita pahami tujuan pendidikan nasional dalam UU No 20 Tahun 2003 tersebut, sebenarnya sudah menggambarkan tujuan yang kompleks sesuai dengan potensi bawaan yang dimiliki peserta didik baik dari ranah afektif, kognitif, dan psikomotorik. Untuk mencapai tujuan tersebut ada beberapa cara yang dilakukan sesuai dengan Renstra Depdiknas yaitu mengembangkan potensi manusia Indonesia melalui: 1) Olah hati untuk memperteguh keimanan dan ketakwaan, meningkatkan akhlak mulia, budi pekerti, atau moral, membentuk kepribadian unggul, membangun kepemimpinan dan entrepreneurship; 2) Olah pikir untuk membangun kompetensi dan kemadirian ilmu pengetahuan dan teknologi; 3) Olah rasa untuk meningkatkan sensitifitas, daya apresiasi, daya kreasi, serta daya ekspresi seni dan budaya; dan 4) Olah raga untuk meningkatkan kesehatan, kebugaran, daya tahan, dan kesigapan fisik serta keterampilan kinestetis. ${ }^{12}$

Menurut M. Arifin tujuan pendidikan jika dilihat menurut tugas dan fungsi manusia secara filosofis dapat dibedakan menjadi tiga sebagai berikut;

1. Tujuan individual, melalui proses belajar dengan tujuan mempersiapkan dirinya dalam kehidupan dunia dan akhirat.

2. Tujuan sosial yang berhubungan dengan kehidupan masyarakat sebagai keseluruhan, dan dengan tingkah laku masyarakat umunya serta dengan perubahan-perubahan yang diinginkan pada pertumbuhan pribadi, pengalaman dan kemajuan hidupnya.

3. Tujuan profesional yang menyangkut pengajaran sebagai ilmu, seni, dan profesi serta sebagai suatu kegiatan dalam masyarakat. ${ }^{13}$

Tiga tujuan pendidikan tersebut harus dicapai secara integral agar mampu menjadikan manusia paripurna sehingga mampu dan siap untuk menghadapi segala perubahan-perubahan yang terjadi sesuai dengan perkembangan ilmu pengetahuan dan teknologi.

\section{Daya Saing Bangsa}

Menghadapi persaingan di era global, berbagai bangsa di dunia telah mengembangkan Knowledge Based Economy (KBE), yang mensyaratkan dukungan manusia berkualitas. Karena itu, pendidikan mutlak diperlukan guna menopang pengembangan ekonomi berbasis pengetahuan Education For The Knowledge Economy (EKE). Dalam konteks ini, lembaga pendidikan harus

\footnotetext{
${ }^{11}$ Indonesia, Undang-Undang No 20 Tahun 2003 tentang Sisdiknas.

${ }^{12}$ Depdiknas, Renstra-Depdiknas-2005-2009, hlm.31

${ }^{13}$ Arifin, Filsafat Pendidikan Islam, hlm.7-8
} 
pula berfungsi sebagai pusat penelitian dan pengembangan, yang menghasilkan produk-produk riset unggulan yang mendukung KBE. Ketersediaan manusia bermutu yang menguasai Iptek sangat menentukan kemampuan bangsa dalam memasuki kompetensi global dan ekonomi pasar bebas, yang menuntut daya saing tinggi. Dengan demikian, pendidikan diharapkan dapat mengantarkan bangsa Indonesia meraih keunggulan dalam persaingan global. ${ }^{14}$

Menurut Sumihardjo mendefinisikan daya saing berasal dari "Kata daya dalam kalimat daya saing bermakna kekuatan, dan kata saing berarti mencapai lebih dari yang lain, atau beda dengan yang lain dari segi mutu, atau memiliki keunggulan tertentu. Artinya, daya saing dapat bermakna kekuatan untuk berusaha menjadi unggul dalam hal tertentu yang dilakukan seseorang, kelompok atau institusi tertentu".15 Sementara itu dalam Permendiknas nomor 41 tahun 2007 tentang standar proses dinyatakan daya saing adalah "kemampuan untuk menunjukkan hasil lebih baik, lebih cepat atau lebih bermakna”.16 Kemampuan yang dimaksud dalam Permendiknas Nomor 41 Tahun 2007 tersebut, diperjelas oleh Sumihardjo meliputi: (1) kemampuan memperkokoh posisi pasarnya, (2) kemampuan menghubungkan dengan lingkungannya, (3) kemampuan meningkatkan kinerja tanpa henti, dan (4) kemampuan menegakkan posisi yang menguntungkan. ${ }^{17}$

Selanjutnya definisi yang berbeda dari World Economic Forum yang dikutip Prasetyo memberikan pengertian bahwa daya saing adalah "himpunan faktor, kebijakan dan kelembagaan yang menentukan tingkat produktivitas suatu negara." Sementara menurut Council of Competitiveness, Washington, DC, daya saing merupakan "kapasitas bangsa untuk menghadapi tantangan persaingan pasar internasional dan tetap menjaga atau meningkatkan pendapatan riil" dari beberapa pendapat di atas penulis menyimpulkan bahwa daya saing adalah kemampuan seseorang atau institusi untuk menunjukkan hasil yang lebih

\footnotetext{
${ }^{14}$ Depdiknas, Renstra-Depdiknas-2005-2009, hlm.33

${ }^{15}$ Tumar Sumihardjo, Penyelenggaraan Pemerintab Daerah Melaui Pengembangan Daya Saing Berbasis Potensi Daerah (Bandung: Fokus Media, 2008), hlm.8

${ }^{16}$ Mendiknas RI, "Peraturan Menteri Pendidikan Nasional Republik Indonesia Nomor 41 Tahun 2007 Tentang Standar Proses," 53 Journal of Chemical Information and Modeling \& (2013), https://doi.org/10.1017/CBO9781107415324.004.

${ }^{17}$ Sumihardjo, Penyelenggaraan Pemerintah Daerah Melaui Pengembangan Daya Saing Berbasis Potensi Daerah, hlm. 11
} 
baik dan cepat atau atau memiliki keunggulan di berbagai faktor dibandingkan dengan orang atau institusi lainnya. ${ }^{18}$

\section{Potret Daya Saing Indonesia}

Peringkat daya saing (Global Competitiveness Index) yang dirilis World Economic Forum (WEF) belum lama ini memperlihatkan posisi Indonesia yang menurun. Pada periode 2015-2016 posisi Indonesia masih berada di peringkat ke-37 dari 140 negara, namun untuk periode 2016-2017 turun ke urutan ke-41. Posisi Indonesia ini berada di bawah negara-negara serumpun seperti Singapura (2), Malaysia, (18) dan Thailand (32), kondisi ini bahkan sudah sejak lama. ${ }^{19}$ Selanjutnya periode 2017-2018 peringkat Indonesia naik menempati posisi ke 36 dari 137 negara. Untuk perbandingan dapat kita lihat pada table berikut posisi daya saing Indonesia dari tahun ke tahun. Dari sumber: The Global Competitiveness Index 2017-2018 edition ${ }^{20}$, menunjukkan adanya peningkatan ranking dan score jika dibandingkan dengan tahun 2016-2017, dari ranking 41 menjadi 36 dan score 4.5 menjadi 4.7. Dengan posisi ini artinya di bawah Indonesia masih ada 101 negara lainnya. Peningkatan posisi tersebut berarti ada upaya perbaikan dan mengarah kepada manajemen perekonomian yang lebih baik pada Negara indonesia. Namun jika dibandingkan dengan Negara serumpun Indonesia masih berada di bawah beberapa Negara-negara tersebut. Dari The Global Competitiveness Index 2017-2018 edition Indonesia menempati posisi ke empat dari Negara-negara serumpun. Dan yang menjadi faktor paling tinggi dalam Most problematic factors for doing business menurut survey tersebut adalah tingkat korupsi Negara Indonesia berada paling atas. ${ }^{21}$

\section{Hubungan Pendidikan dan Daya Saing Bangsa}

Menurut Prof. Wijojo Nitisastro yang dikutip Prima Roza mengatakan bahwa "dalam melaksanakan pembangunan kita tidak boleh melupakan unsur manusia yang ada di dalamnya. Penduduk harus ditempatkan sebagai titik sentral

\footnotetext{
${ }^{18}$ Prasetyo, "Penguatan Daya Saing SDM Untuk Keunggulan Bbangsa. Pusat Kajian

Dan Informasi Keuangan Daerah,” accessed January 29, 2019, https://pekikdaerah.wordpress.com/2010/10/01/507/.

${ }^{19}$ Bagus, "Memperbaiki Daya Saing Indonesia - Direktorat Jenderal Kelembagaan

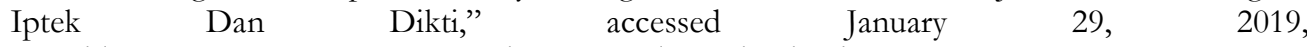
http://kelembagaan.ristekdikti.go.id/index.php/2017/04/11/memperbaiki-daya-saingindonesia/.

${ }^{20} \mathrm{WEF}$, The Global Competitiveness Report 2017-2018, Word Economic Forum (Geneva, 2017), https://doi.org/92-95044-35-5.

${ }^{21} \mathrm{WEF}$.
} 
pembangunan. Pertumbuhan ekonomi tidak akan berjalan jika tidak didukung sumber daya manusia (SDM) yang berkualitas. Sebaliknya, pertumbuhan SDM yang berkualitas tidak akan bisa terjadi tanpa adanya pertumbuhan ekonomi". ${ }^{22}$ Dalam konsep pembangunan sebuah Negara bukan hanya sekedar pembangunan infrastruktur berupa jalan, gedung, irigasi dan lainnya dengan mengabaikan pembangunan SDM. Pertumbuhan ekonomi, tidak akan berhasil tanpa didukung oleh pendidikan sebagaimana yang dikemukakan Alhumami yang diikuti Subroto bahwa "pendidikan bukan hanya melahirkan sumber daya yang berkualitas, memiliki pengetahuan dan keterampilan, serta menguasai teknologi, melainkan juga dapat menumbuhkan iklim bisnis yang sehat dan kondusif bagi pertumbuhan ekonomi". ${ }^{23}$

SDM yang berkualitas pada dasarnya adalah yang memiliki keahlian, kemampuan, keterampilan untuk melakukan sesuatu kegiatan dalam menghasilkan barang atau jasa yang ikut serta menetukan kualtas hidupnya. Untuk peningkatan kualitas SDM, dapat dilakukan melalui 3 jalur utama, yaitu; Jalur pendidian formal, Terdiri dari pendidikan umum dan kejuruan mulai dari tingkat sekolah dasar, sekolah menengah tingkat pertama dan atas, dan perguruan tinggi.

Jalur latihan kerja. Jalur ini merupakan proses pengembangan keahlian dan ketrampilan kerja. Tujuan latihan kerja ini adalah meningkatkan kemampuan profesional dan mengutamakan praktek daripada teori. Jalur pengalaman kerja. Yaitu wahana di mana seseorang dapat meningkatkan pengetahuan teknis maupun ketrampilan kerjanya dengan mengamati orang lain, menirukan, dan melakukan sendiri tugas-tugas pekerjaan yang ditekuninya. ${ }^{24}$

Begitu urgennya pendidikan dalam menetukan kualitas SDM sebagai salah satu unsur utama dalam menopang pembangunan bangsa. Seperti yang dinyatakan Abuddin Nata bahwa ketahanan masyarakat ditentukan oleh tiga unsur, yaitu SDA, SDM yang berkualitas, dan sumberdaya kebudayaan dan kesejahteraan.25 Di dalam survey The Global Competitiveness Index untuk

22 Roza, “Pendidikan Dan Mutu Manusia,” Jurnal Sosioteknologi 6, no. 12 (2007): $303-8$.

${ }^{23}$ Gatot Subroto, "Hubungan Pendidikan Dan Ekonomi: Perspektif Teori Dan Empiris," Jurnal Pendidikan Dan Kebudayaan 20, no. 3 (2014): 390-400.

${ }^{24}$ Ika Ruhana, "Pengembangan Kualitas Sumber Daya Manusia Vs Daya Saing Global," Jurnal Administrasi Bisnis 6, no. 1 (2012): 51-56, http://ejournalfia.ub.ac.id/index.php/profit/article/view/134.

${ }^{25}$ Abuddin Nata, Kapita Selekta Pendidikan Islam, Isu-Isu Kontemporer Tentang Pendidikan Islam (Jakarta: PT. Raja Grafindo Persada, 2012), hlm. 57 
menentukan pemeringkatan WEP berdasarkan 12 pilar indikator diantaranya sebagai indikatornya adalah pendidikan dan pelatihan. Ke-12 pilar itu melputi kondisi-kondisi dari:

1. Institution (kelembagaan negara bersangkutan)

2. Infrstructure (infrastrukturnya)

3. Macroeconomic Enviroment (stabilitas makro ekonomi),

4. Health and Primary Education (tingkat kesehatan dan pendidikan dasar),

5. Higher Education and Training (pendidikan tinggi serta intensitas pelatihanpelatihan),

6. Goods Market Efficiency (efisiensi dalam usaha perdagangan),

7. Labor Market Efficiency (efisiensi pasar tenaga kerja),

8. Financial Market Development (keunggulan pasar keuangan),

9. Technological Readiness (ketersediaan teknologi),

10. Market Size (keterjangkauan pasar),

11. Business Sophistications (kecanggihan berbisnis),

12. Innovation (kemampuan inovasi). ${ }^{26}$

Sementara itu menurut Menurut Michael Porter dalam Sudarmanto ada 4 (empat) faktor yang mempengaruhi daya saing suatu bangsa yaitu 1) strategi, struktur, dan tingkat persaingan perusahaan, yaitu berkaitan dengan bagaimana unit-unit usaha dalam suatu negara terbentuk, diorganisasikan, dikelola, dan bagaimana tingkat persaingan dalam negeri; 2) sumber daya yang tersedia pada suatu negara, yaitu sumber daya manusia, bahan baku, pengetahuan, modal, dan infrastruktur; 3) permintaan domestik, yaitu bagaimana kondisi permintaan dalam negeri terhadap produk atau layanan industri di negara tersebut; dan 4) keberadaan industri terkait dan pendukung, yaitu bagaimana keberadaan industri pemasok (industri pendukung) dan kemampuannya bersaing secara internasional. ${ }^{27}$

Hasil perankingan pada pilar pendidikan tinggi dan intensitas pelatihan yang dilakukan oleh The Global competitiveness Report posisi Negara Indonesia dapat dilihat pada The Global Competitiveness Index 2017-2018 edition, dapat diketahui bahwa posisi Indonesia pada pilar pendidikan tinggi dan intensitas pelatihan berada pada ranking 64 dari 137 negara dengan skor 4.5 dari 7 skala yang dibuat. Ranking terendah terdapat pada komponen Tertiary education enrollment rate (tingkat partisipasi pada perguruan tinggi). Pada pilar healt and

\footnotetext{
${ }^{26}$ WEF, The Global Competitiveness Report 2017-2018.

${ }^{27}$ Sudarmanto, "Pengembangan Kewirausahaan Dan Daya Saing Bangsa Melalui Pendidikan Karakter” (Lampung: Universitas Bandar Lampung, 2011), 1-17.
} 
primary education pada komponen primary education enrollment rate Indonesia menempati ranking 106 dari 137 negara dengan nilai net 89.7\%. Artinya tingkat pendidikan di Negara Indonesia lebih banyak yang masih berada pada pendidikan dasar dari pada pendidikan tinggi. Hal ini senada yang diungkapkan juga oleh Agus Swignyo dalam harian kompas berdasarkan data BPS "sampai tahun 2017 sekitar sepertiga penduduk Indonesia usia di atas 15 tahun hanya mengenyam pendidikan SD. Di antara lulusan SD yang melanjutkan hingga tamat sekolah menengah pertama (SMP), sekitar 75 persennya meneruskan ke sekolah lanjutan atas (SLA; SMA/SMK), tetapi hanya sekitar 80 persen dari 75 persen itu yang bertahan sampai tamat SLA. Postur tenaga kerja Indonesia saat ini terbesar berpendidikan SD (28,03\%) dan SLA (25,1\%). Postur ini tidak jauh berbeda dengan data tahun $1996 .{ }^{28}$

Lebih lanjut suwignyo menyatakan Banyaknya tenaga kerja pada kelompok (cohort) lulusan SD dan lulusan SLA mungkin menjadi faktor mengapa pengangguran tertinggi berasal dari kelompok penduduk dengan dua kategori pendidikan tersebut. Artinya, bukan hanya mutu, melainkan juga keterbatasan akses pendidikan dan keberlanjutan sekolah menjadi faktor penyumbang bagi rendahnya daya saing bangsa ini. Di satu sisi, pendidikan belum menjadi daya tarik bagi warga Negara dan kesadaran warga tentang pentingnya pendidikan belum merata. Hal ini menjadi tantangan tersendiri bagi bangsa ini untuk terus meningkatakan upaya-upaya dalam mengatasi permasalahan tersebut. ${ }^{29}$

Karena pendidikan saah satu indikator dalam daya saing bangsa maka untuk menghaslikan SDM berkualitas tentunya dibutuhkan pendidikan yang berkualitas. Berbicara pendidikan yang berkualitas maka berbicara dengan mutu pendidikan itu sendiri. Karena mutu pendidikan yang akan menjadikan out put pendidikan berkualitas atau tidak. Strategi pembangunan SDM Nata mengungkapkan ada dua sisi yang harus diperhatikan yaitu sisi internal dan eksternal. Pada sisi internal yaitu sebagai upaya dalam memberdayakan potensi al-Insaniyah, al-Basyar, dan al-Naas30 dengan menempatkan peserta didik

${ }^{28}$ Agus Suwignyo, "PressReader.Com - Connecting People Through News," Harian Kompas, 2018, https://www.pressreader.com/.

${ }^{29}$ Agus Suwignyo.

${ }^{30}$ Lihat dalam Nata, Kapita Selekta Pendidikan Islam, Isu-Isu Kontemporer Tentang Pendidikan Islam, hlm. 63-64. Al-Insaniyah menunjukkan manusia sebagai makhluk yang dapat menerima pelajaran, mampu memanfaatkan waktu, memikul amanah, keterkaitan dengan moralitas, mampu melakukan perubahan social, memimpin, menembus ruang agkasa, beribadah dan hidup di alam akhirat. Al-Basyar menggambarkan dimensi fisik manusia yang membutuhkan makan, 
sebagai subjek dalam pendidikan. Pada sisi eksternal sebagai upaya memberikan ilmu pengetahuan, wawasan, keterampilan, pengalaman, nilai-nilai dan lain sebagainya dengan menempatkan peserta didik sebagai objek dalam pendidikan. Dan pembangunan SDM harus memadukan kepentingan internal dan eksternal, yaitu di samping memberdayakan manusia bagi kepentingan pasar juga manusia yang beriman dan bertakwa, berakhlak mulia, berkarakter, serta berkeperibadian mulia. ${ }^{31}$

Uraian di atas menunjukkan adanya hubungan antara pendidikan dan daya saing bangsa diantaranya berdasarkan laporan dari The Global competitiveness Report salah satu pilar sebagai indikator daya saing bangsa adalah pendidikan, maka untuk meningkatkan daya saing bangsa Indonesia harus dengan memperbaiki dari 12 pilar tersebut yang salah satunya bidang pendidikan. Lebih lanjut Menurut Michael Porter salah satu pilar penentu daya saing adalah sumber daya yang tersedia di suatu Negara, diantaranya SDM. Kualitas SDM kemudian ditentukan oleh pendidikan, semakin tinggi tingkat partisipasi pendidikan dan semakin baik mutu pendidikan maka akan semakin baik out put yang dihasilkan. SDM yang berkualitas menjadi salah satu faktor penentu untuk menumbuhkan suasana bisnis yang kondusif sehingga mampu membantu pertumbuhan ekonomi, karena terdapat hubungan timbal balik antara pendidikan dengan ekonomi bangsa.

Pendidikan tidak hanya membantu pertumbuhan ekonomi, namun lebih luas lagi pendidikan akan mempengaruhi keunggulan suatu bangsa dalam berbagai bidang, baik politik, pertahanan keamanan dan sosial budaya. Dalam perspektif budaya, pendidikan di era global menjadi wahana penting dan medium yang efektif dalam mengajarkan norma, menyosialisasikan nilai dan menanamkan etos dikalangan umat Islam. ${ }^{32}$ Dalam sejarah peradaban Islam membuktikan bagaimana Islam sebagai pusat peradaban dunia ketika zaman keemasan Islam (golden age) pada masa dinasti Abbasiyah ditandai oleh kemajuan dalam bidang ilmu pengetahuan, kebudayaan dan peradaban yang mengagumkan. Berbagai kemajuan yang dicapai dunia Islam tersebut tidak mungkin terjadi tanpa didukung oleh kemajuan dalam bidang pendidikan, karena

minum, melakukan hubungan seks, memiliki cirri yang sama, proses penciptaan dan bahan dasar yang sama, dan akhirnya akan menemua ajalnya. Al-naas menunjukkan manusia sebagai makhluk social, saling membutuhkan antara satu dan lainnya.

${ }^{31}$ Nata, hlm. 65-66

32Zubaedi, Isu-Isu Baru Dalam Diskursus Filsafat Pendidikan Islam Dan Kapita Selekta Pendidikan Islam (Yogyakarta: Pustaka Pelajar, 2012), hlm. 98 
pendidikanlah yang menyiapkan sumber daya insani yang menggerakkan kemajuan tersebut. ${ }^{33}$

Pelajaran yang sangat berharga dari sejarah kejayaan dunia Islam ketika itu melalui pendidikan yang didukung oleh para khalifah yang cinta ilmu pengetahuan dalam menentukan kebijakan pembangunan SDM bisa dijadikan sebagai falsafah suatu Negara dalam meningkatkan daya saing bangsa. Jika suatu bangsa tidak mampu untuk menghadapi tantangan-tantangan yang semakin maju dan terus berkembang di era global ini, maka seperti yang selalu dikatakan Bung Karno, Een Natie Van Koelias En Een Koelie Onder De Naties, "bangsa yang tidak berdaya saing akan menjadi bangsa kuli dan kulinya bangsa lain”.

\section{Penutup}

Daya saing bangsa ditentukan oleh berbagai indikator, salah satunya adalah pendidikan dan SDM, karena SDM sebagai penggerak terhadap kemajuan suatu bangsa, walaupun kekayaan Sumber Daya Alam yang melimpah tanpa didukung SDM yang berkualitas maka akan sia-sia. SDM yang berkualitas hanya dapat dihasilkan dan ditingkatkan melalui pendidikan, baik formal, non formal dan informal serta latihan kerja dan pengalaman kerja. Indonesia sebagai Negara yang besar memiliki potensi dalam meningkatkan daya saing bangsa pada taraf internasional sebagai Negara yang makmur dan mandiri. Melalui perubahan paradigma bangsa dalam pemberdayaan SDM, mengembangkan ilmu pengetahuan dan teknologi, dan kebijakan pemerintah dalam pembangunan bangsa dengan memberikan perhatian lebih besar pada peningkatan SDM melalui pemerataan akses pendidikan dan pemertaan mutu pendidikan.

\section{Bibliography}

Agus Suwignyo. "PressReader.Com - Connecting People Through News." Harian Kompas, 2018. https://www.pressreader.com/.

Arifin, Muzayyin. Filsafat Pendidikan Islam. Jakarta: PT. Bumi Aksara, 2003.

Bagus. "Memperbaiki Daya Saing Indonesia - Direktorat Jenderal Kelembagaan Iptek Dan Dikti." Accessed January 29, 2019. http://kelembagaan.ristekdikti.go.id/index.php/2017/04/11/memperb aiki-daya-saing-indonesia/.

Depdiknas. Renstra-Depdiknas-2005-2009 (2005). 
Ihsan, Fuad. Dasar-Dasar Pendidikan. Jakarta: PT.Rineka Cipta, 2005.

"Indonesia Masuk 10 Negara Dengan Kualitas Sains Terendah | Databoks." Accessed January 2019. https://databoks.katadata.co.id/datapublish/2016/12/21/indonesiamasuk-10-negara-dengan-kualitas-sains-terendah.

Indonesia, Republik. Undang-Undang No 20 Tahun 2003 tentang Sisdiknas, Pub. L. No. 20 (2003).

Mendiknas RI. Peraturan Menteri Pendidikan Nasional Republik Indonesia Nomor 41 Tahun 2007 Tentang Standar Proses, 53 Journal of Chemical Information and Modeling https://doi.org/10.1017/CBO9781107415324.004.

Nata, Abuddin. Kapita Selekta Pendidikan Islam, Isu-Isu Kontemporer Tentang Pendidikan Islam. Jakarta: PT. Raja Grafindo Persada, 2012.

- Sejarah Pendidikan Islam. Jakarta: Kencana, 2011.

Prasetyo. "Penguatan Daya Saing SDM Untuk Keunggulan Bbangsa. Pusat Kajian Dan Informasi Keuangan Daerah.” Accessed January 29, 2019. https://pekikdaerah.wordpress.com/2010/10/01/507/.

Roza. "Pendidikan Dan Mutu Manusia.” Jurnal Sosioteknologi 6, no. 12 (2007):

Ruhana, Ika. "Pengembangan Kualitas Sumber Daya Manusia Vs Daya Saing Global." Jurnal Administrasi Bisnis 6, no. 1 (2012). http://ejournalfia.ub.ac.id/index.php/profit/article/view/134.

Subroto, Gatot. "Hubungan Pendidikan Dan Ekonomi: Perspektif Teori Dan Empiris.” Jurnal Pendidikan Dan Kebudayaan 20, no. 3 (2014).

Sudarmanto. "Pengembangan Kewirausahaan Dan Daya Saing Bangsa Melalui Pendidikan Karakter," 1-17. Lampung: Universitas Bandar Lampung, 2011.

Sumihardjo, Tumar. Penyelenggaraan Pemerintah Daerah Melaui Pengembangan Daya Saing Berbasis Potensi Daerah. Bandung: Fokus Media, 2008.

Umar, Bukhori. Ilmu Pendidikan Islam. 1st ed. Jakarta: Amzah, 2010. 
United Nations. "Human Development Indices and Indicators: 2018 Statistical Update,"2018.http://hdr.undp.org/sites/default/files/hdr2018_technic al_notes.pdf.

WEF. The Global Competitiveness Report 2017-2018. Word Economic Forum. Geneva, 2017. https://doi.org/92-95044-35-5.

Zubaedi. Isu-Isu Baru Dalam Diskursus Filsafat Pendidikan Islam Dan Kapita Selekta Pendidikan Islam. Yogyakarta: Pustaka Pelajar, 2012. 